\title{
A new sustainable city in the Egyptian western desert: Gardens' City
}

\author{
S. Abouelfadl ${ }^{1}$, K. Ouda ${ }^{2}$, A. Atia ${ }^{3}$, N. Al-Amir ${ }^{3}$, M. Ali ${ }^{3}$, \\ S. Mahmoud ${ }^{3}$, H. Said ${ }^{3}$ \& A. Ahmed ${ }^{3}$ \\ ${ }^{1}$ Architectural Department, College of Engineering, \\ Assuit University, Egypt \\ ${ }^{2}$ Department of Geology, College of Science, Assuit University, Egypt \\ ${ }^{3}$ Architect, Assuit, Egypt
}

\begin{abstract}
There are newly discovered areas in the Egyptian western desert, which were believed to be part of the Great Sand Sea. These areas are able to be developed. Water is available near ground surface in the area; the new Farafra Oasis lies in these areas. This paper discusses a general master plan of the Gardens' City, as a future city in new Farafra Oasis. The aim of the paper is to achieve sustainability in the city during the planning stage.

The city is planned for 117,000 inhabitants, with a final target of settling 1 million inhabitants in the oasis. Palm, olive and wheat are economical bases in the oasis and limestone and shale/clay soil form local building materials there. The White Desert forms a beautiful touristic site near the oasis. The industrial economy is based mainly on agriculture in addition to other local resources.

The city plan includes a field to generate renewable energy from the sun and wind, which are available on the site. Algae will be planted there to produce biofuel. The city will be sustainable from different sides, especially energy.

Keywords: sustainable city, city planning, Gardens' City, renewable energy, Egyptian western desert, new Farafra Oasis, sustainable planning.
\end{abstract}

\section{Introduction}

Cities are motors for sustainable development and are thus of crucial importance for the future. Management of complex systems such as cities requires the use of innovative and sophisticated planning. 
Considering the threat of fresh water scarcity in Egypt; the expected effects of global warming on it especially in coastal and delta regions, in addition to national needs to create new urban communities outside the scope of the Nile Valley, this paper discusses a general master plan of the Gardens' City with the aim to achieve sustainability in it. Gardens' City lies in the Egyptian's western desert in newly discovered to be developed areas [1]. This city is the first product of big development opportunities in Egypt. Figure 1 shows the site of these discovered areas with a road to be initiated to connect it to the Nile Valley, and the site of new Farafra Oasis $\left(932 \mathrm{~km}^{2}\right)$ where the Gardens' City is planned.

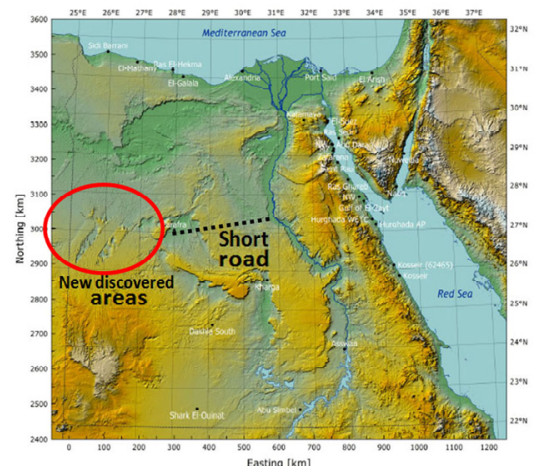

(a) Newly discovered areas and to be initiated, the road to Nile Valley $(180 \mathrm{~km})$

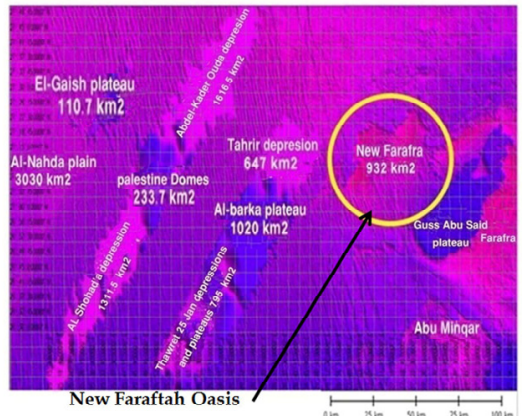

(b) Newly discovered areas in the Egyptian western desert [2].

Figure 1: Newly discovered areas in the western Egyptian desert and new Farafra Oasis.

\section{Site potentials}

Water is available under the Egyptian desert. Figures 2(a) and (b) show the Nubian sandstone, water storage holder, extension through territorial limits of the states involved and the depth of water storage which reaches $3500 \mathrm{~m}$ under the new Farafra Oasis. Solar radiation is intense $\left(6.6-6.7 \mathrm{kwh} / \mathrm{m}^{2} /\right.$ day $)$ and wind velocity reaches $7 \mathrm{~m} / \mathrm{s}$ (figure $2(\mathrm{c})$ and (d)). Limestone and shale clay soil are available for local building materials in the oasis. A touristic site "White Desert National Park" lies near its site. Large amounts of white sand are also found near the site, which will be used for manufacturing glass and solar cells.

\section{The Gardens' City primary master plan}

The city is planned for 117,000 inhabitants, with a final target of settling 1 million inhabitants in the new Farafra Oasis. A part of the city is used for farm 


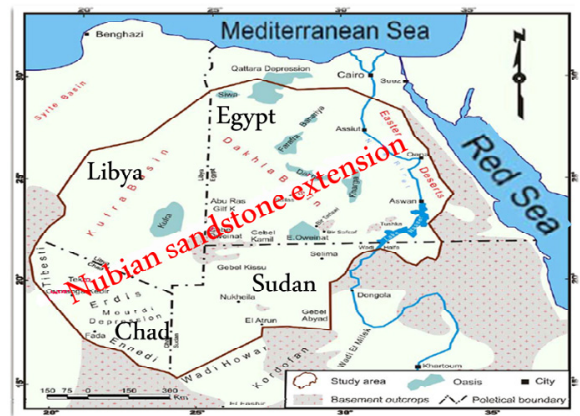

(a) Water availability under the Egyptian western desert. The thickness of Nubian sandstone is $2500-3500 \mathrm{~m}$ in the Great Sand Sea in Egypt [2].

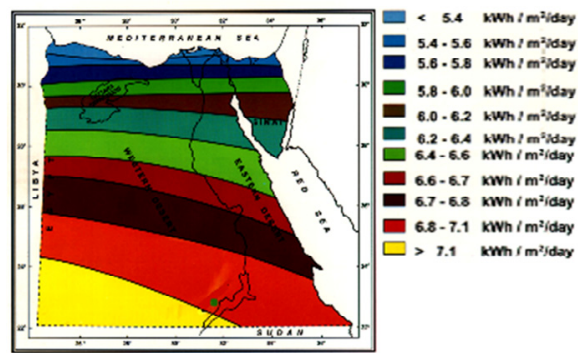

(c) Solar radiation distribution in Egypt potentials of energy generation [3].

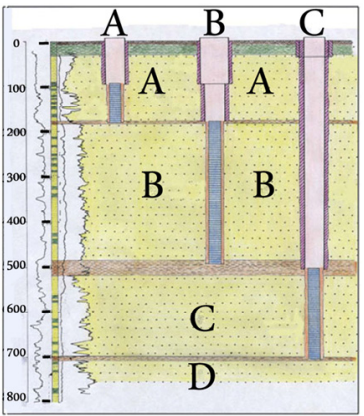

(b) Water storage depth in new Farafra Oasis is $3500 \mathrm{~m}$ in the Dala natural springhead area [2].

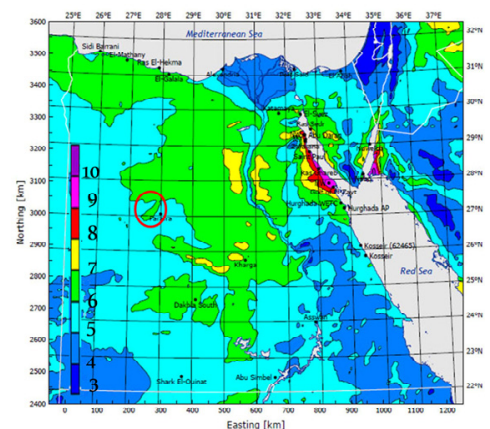

(d) Wind speed in Egypt potentials of energy generation [4].

Figure 2: Site potentials.

houses; each farm house covering an area of 600-1000 $\mathrm{m}^{2}$. A house will be built over $150 \mathrm{~m}^{2}$ and the rest of land piece will be used for agricultural farming. The farm is used in planting crops like tomatoes, potatoes, carrot, etc.; vegetables and fruit, supply daily food for the city. Another part of the city is for barn houses where animals like chicken, rabbits, ducks, etc, will be raised. The whole city will be supplied with these animals and birds' meat, eggs, etc. South to the city lies barns for bigger animals like cattle, sheep; 750,000 heads will be raised there. Animals' rests will be used to produce biogas and fertilizer to cultivate agricultural land. Since the nearby desert area is famous for its palms and olives, a big garden will be used to plant palms. Another garden is for planting olive trees. Wheat will be the main crop in an area of 15 thousands feddans (one hectare $=2.381$ feddans) south to Gardens' City, which will be used for agriculture. Other economical crops will be planted there in non-wheat season. 123,200 palms and 79,200 olive trees and wheat will be the economical bases of Gardens' City. Industries based on them with animals, and plants and animals rests will be initiated in the industrial area. A lake for sanitary water is behind 
the industrial area. This lake will be used for planting algae to produce biofuel. The first college of renewable energy in Egypt is designed to be in the university area of the city. The first environmental agricultural college and institutes for developing plants and animals will also be there. Building material industries based on local materials in addition to glass and solar cell industries from the white sand near the oasis will be initiated. An energy garden of an area of 9000 feddans lies near the city site for generating renewable energy from the sun and wind. Each city zone has its future expansion area. Figure 3 shows a primary master plan for the city, and table 1 shows the land use of it.

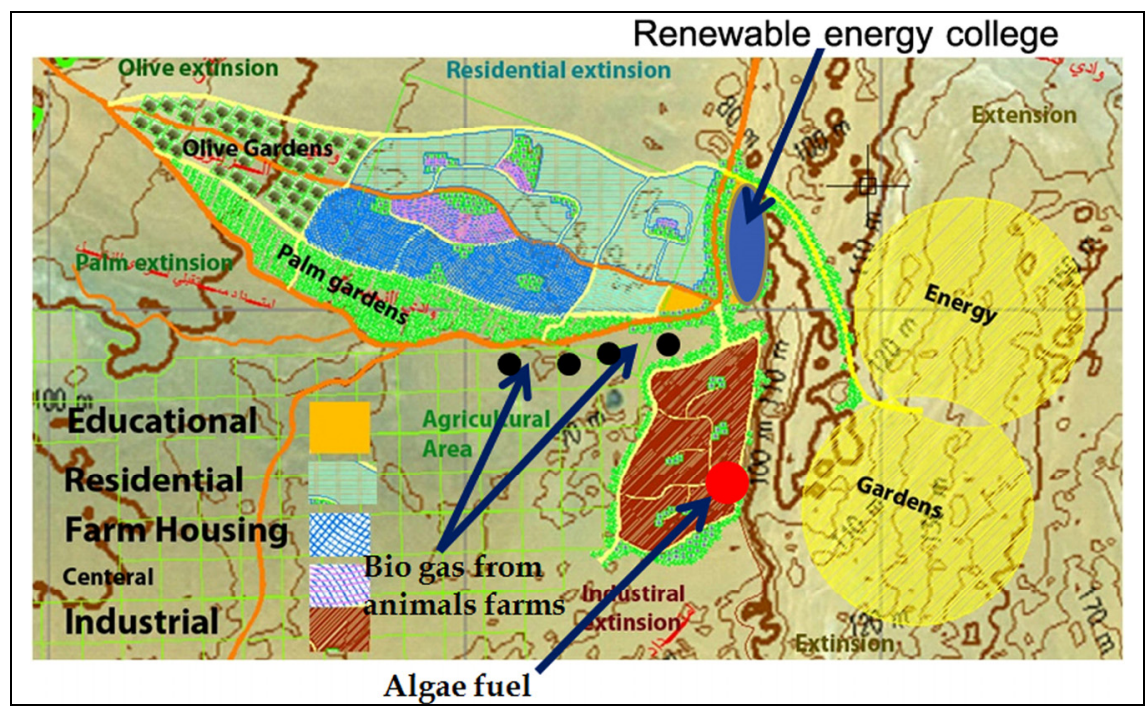

Figure 3: A primary master plan for Gardens' City.

Table 1: $\quad$ Land use of Gardens' City ( 1 hectare $=2.381$ feddan $)$.

\begin{tabular}{|c|c|c|c|c|}
\hline Land use & Area/person or piece & Area feddan & Units & $\%$ \\
\hline Housing & $43.3 /$ person & 1140 & & 33.4 \\
\hline Farm housing & $600-1000 \mathrm{~m}^{2} /$ piece & 490 & 2500 & 14.4 \\
\hline Barn housing & $240 \mathrm{~m}^{2}$ & 240 & 800 & 7.0 \\
\hline Educational & $6 \mathrm{~m}^{2}$ & 172 & & 5.0 \\
\hline University & & 216 & & 6.3 \\
\hline Services & $12.77 \mathrm{~m}^{2}$ & 356 & & 10.4 \\
\hline Industrial & $28.7 /$ person & 800 & & 23.5 \\
\hline Total city area & & 3414 & & 100 \\
\hline Palm Gardens & 770 feddans & 160 palm/feddan & 123,200 & \\
\hline Olive Gardens & 660 feddans & 120 tree/ feddan & 79,200 & \\
\hline Energy Gardens & & Up to 9000 & & \\
\hline
\end{tabular}




\section{Sustainability}

Sustainability is achieved in planning the Gardens' City from different points of view, as follows.

\subsection{Sustainable land use}

The city respects guidelines for incorporating ecological principles into land-use decision making. These guidelines suggest that land managers should: examine impacts of local decisions in a regional context, plan for long-term change and unexpected events, preserve rare landscape elements and associated species, avoid land uses that deplete natural resources, retain large contiguous or connected areas that contain critical habitats, minimize the introduction and spread of non-native species, avoid or compensate for the effects of development on ecological processes, and implement land-use and management practices that are compatible with the natural potential of the area. Figure 4 shows general features of the city.

\section{General features}
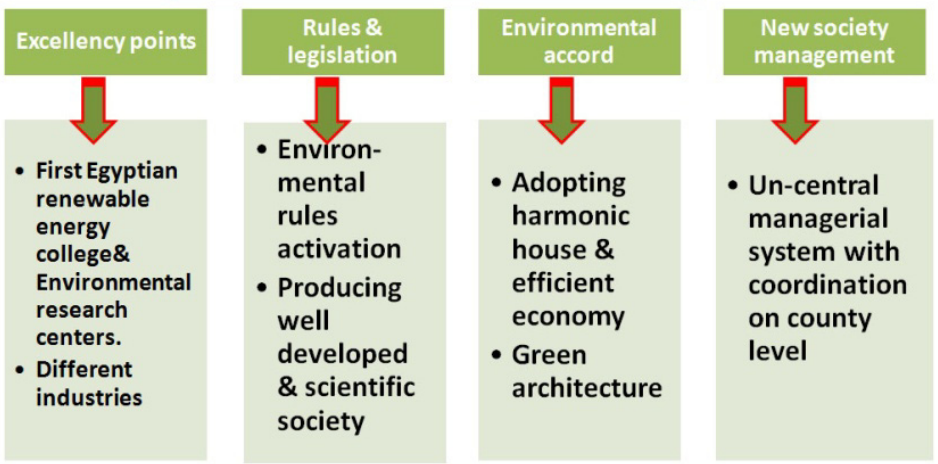

Figure 4: General features of Gardens' City.

\subsection{Sustainable agricultural and processing inputs}

A sustainable agriculture system is followed. A good understanding of the nature of interactions between the four main components of an integrated system of agricultural production, which are fertilizers, pesticides, cultivations and rotations, and how these interactions influence crop yields and farm income. Integrated pest management; pest and disease forecasting; biological and cultural pest control; living mulches and mechanical weed control; conservation tillage; specialized innovative cultural techniques, including intercropping, strip cropping, under sowing, trap crops, and double-row cropping. The components of agricultural systems will be fully integrated. Fully integrated farming systems 
that minimize energy-based chemical inputs, produce good yields, increase farm profits and decrease environmental problems is being designed [5].

\subsection{Sustainable use of residues and waste}

A sustainable use of residues and waste is followed in the city. House waste will be recycled. Crops and plants rest will be used in feeding animals. Animal and crops rests will be used in producing biogas and fertilizers for cultivating agricultural land. For the purposes of the GHG-savings criterion, waste is "considered to have zero life-cycle greenhouse gas emissions up to the process of collection of those materials," meaning no land-use (including soil carbon) emissions.

\subsection{Sustainable complementary fellings}

The gap between the level of fellings and the increment in growing stock provides an opportunity to use forestry biomass that currently remains unexploited as a source of renewable energy. This opportunity is identified as complementary fellings. How much bio-energy could be produced without harming the environment? This leads to a huge overestimation of woody biomass reserve. Complementary fellings will be used for manufacturing landscape, furniture, shades, etc. sculptures and bio-energy.

\subsection{Sustainable energy}

Gardens' City has an energy garden of an area of 9000 feddan $\left(37.9 \mathrm{~km}^{2}\right)$. Half of this energy garden is for producing energy from the sun. As 1 Megawatt is used to supply around 1000 houses on average [6], and Gardens' City has 117,000 inhabitants, then it needs 24 Megawatt. As an area of between 72$216 \mathrm{~km}^{2}$ is enough for supplying 1000 Megawatt [7], then an area of $18 \mathrm{~km}^{2}$ (half of energy garden) is enough to supply 180 Megawatt, which is more than what the whole of new Farafra Oasis needs. Houses and buildings will also be supplied with solar and wind energy appliances to generate their own energy.

A windmill of an area of 50 acres produces 1 Megawatt [8]. Then an area of $18 \mathrm{~km}^{2}$ (half of energy garden) is enough to supply 180 Megawatt, which is more than what the whole of new Farafra Oasis needs. Animals' and part of plants' rest will be used to produce biofuel. Algae will be also planted in the sanitary lack behind the industrial area for producing biofuel. All these sources of renewable energy will keep Gardens' City energy sustainable.

This means that Gardens' City with its energy garden and biofuel is able to supply not only new Farafra Oasis but more than that. It will be a main station to supply the new discovered Egyptian areas as well.

Prices of solar and wind energy are going to reduce more and more. Their prices are expected to be between 30-50\% from on 2010 [9]. The WWF scenario of the world by 2050 suggests that there will be almost complete dependence on renewable energy [10] (as shown in figure 5). This means that Gardens' City is in harmony with the world's thoughts for the future. 


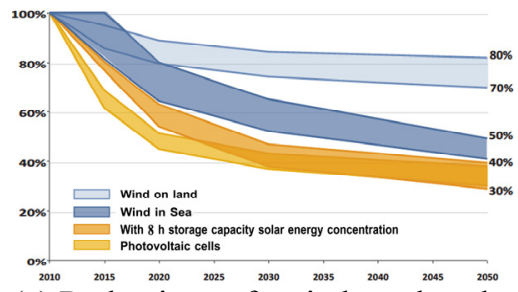

(a) Reduction of wind and solar energy prices until 2050 [9].

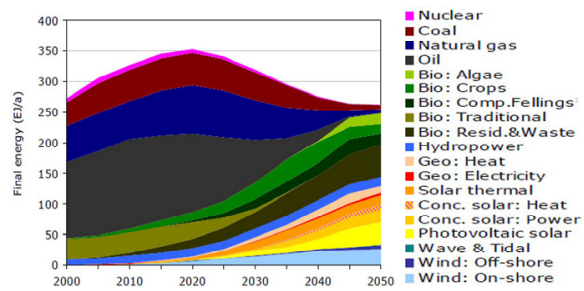

(b) Global energy supply in the WWF scenario, split by source (including traditional biomass use) [10].

Figure 5: Future reduction of renewable energy and future expectation world energy scenario.

\section{Gardens' City general master plan}

The primary master plan for Gardens' City has been developed. Residential areas have been designed in neighborhoods with their own services (educational, religious, social, health, recreational, commercial services, etc). The central area has the city central services. Table 2 shows city services. Figure 6 shows a general master plan of the city, while figure 7 shows city land use, roads, services distribution and a design of a neighborhood and its centre. Each housing cluster in the neighborhood has its own landscape area. Housing design depends on passive design to afford a suitable indoor climate. Figure 8 shows a house and house group design. There is Egyptian energy legislation, which is not yet mandatory; this will be activated in Gardens' City.

Table 2: $\quad$ Services for Gardens' City.

\begin{tabular}{|c|c|c|c|c|c|c|}
\hline$\underbrace{\stackrel{ల}{\infty}}_{\infty}$ & $\stackrel{\widetilde{\Xi}}{\Xi}$ & $\stackrel{\mathscr{\Xi}}{\Xi}$ & 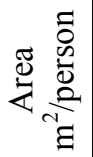 & 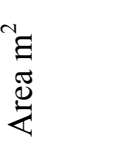 & 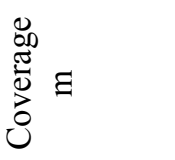 & 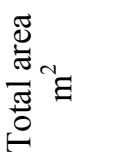 \\
\hline \multirow[t]{2}{*}{ Educational } & Primary school & 23 & 10 & 20,000 & 400 & 160,000 \\
\hline & Kindergartens & 71 & 15 & 500 & $200-300$ & 35,500 \\
\hline Commercial & Com-centers & 23 & & 12,000 & 500 & 276,000 \\
\hline Religious & & 23 & 0.4 & 2000 & $150-200$ & 46,800 \\
\hline \multirow[t]{2}{*}{ Public } & Social centers & 23 & & 1000 & & 23,000 \\
\hline & Health centers & 23 & 0.06 & 60 & 400 & 7020 \\
\hline Gardens & $\begin{array}{l}\text { neighborhood } \\
\text { centers }\end{array}$ & & 0.6 & 3000 & $\begin{array}{l}15000 \\
\text { inhabitant }\end{array}$ & 70,200 \\
\hline
\end{tabular}




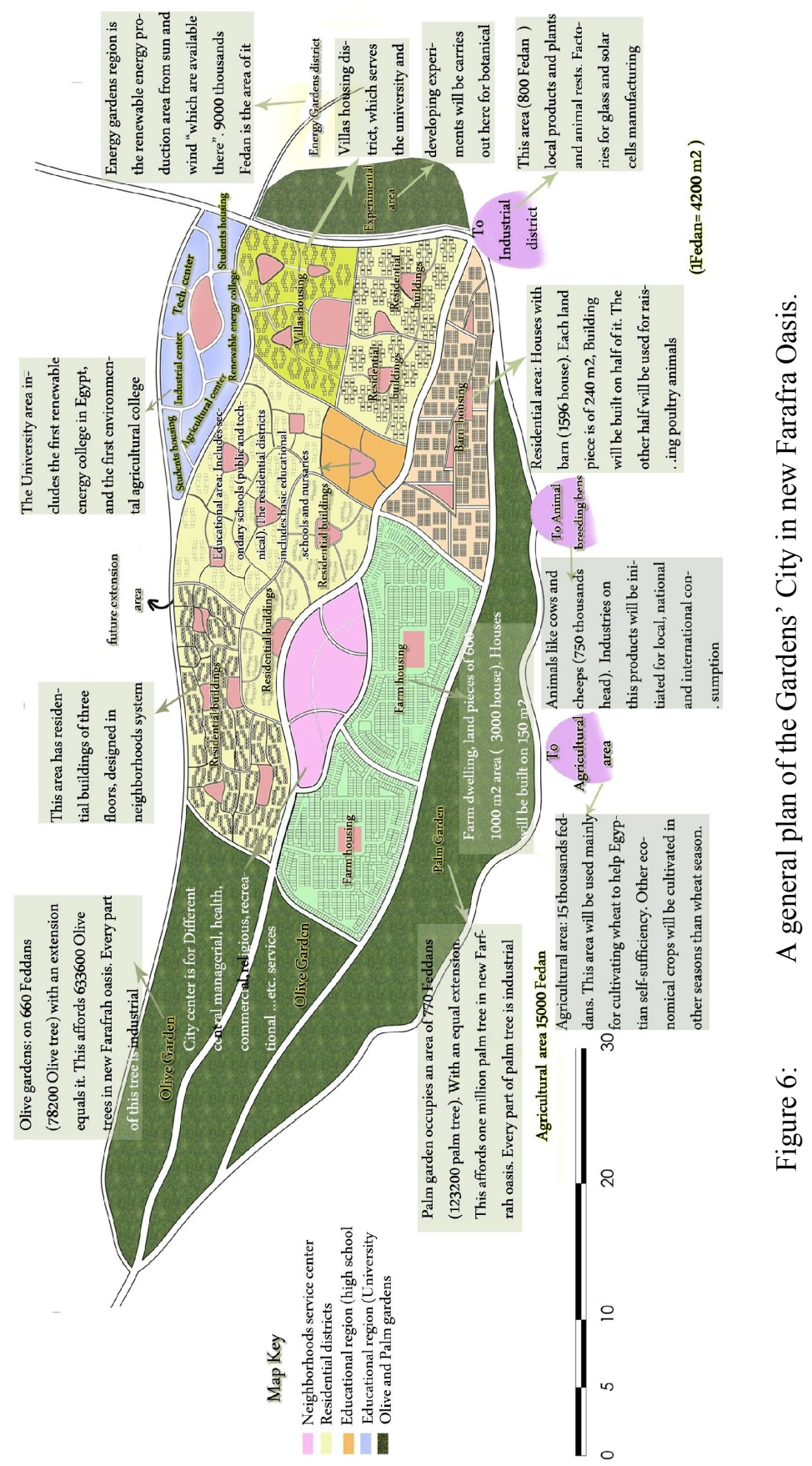

WIT Transactions on Ecology and The Environment, Vol 181, (C) 2014 WIT Press www.witpress.com, ISSN 1743-3541 (on-line) 


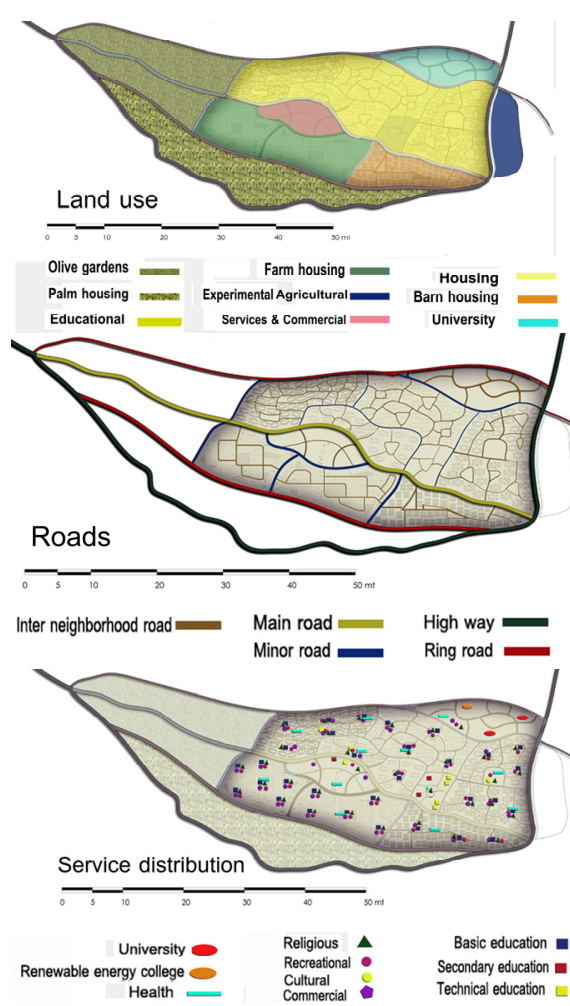

(a) land use, roads and services distribution
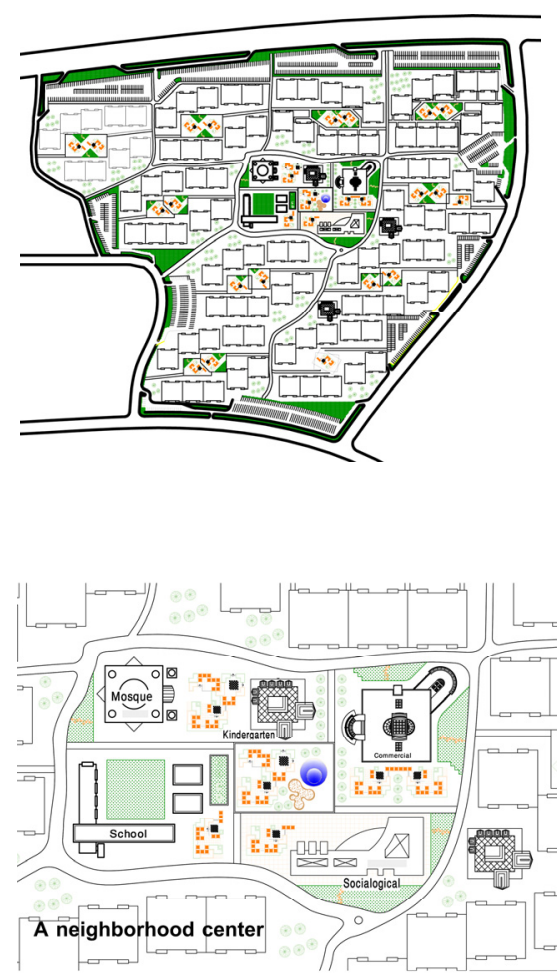

(b) a neighborhood and its center

Figure 7: Gardens' City land use, roads and services.

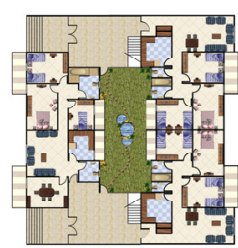

Ground floor

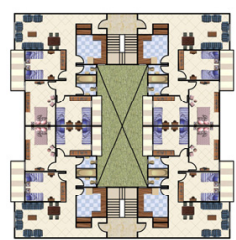

Repetitive floor

(a) a house design

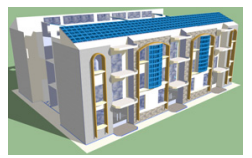

(b) 3D of housing group

Figure 8: A neighborhood design and its center in Gardens' City accompanied by a housing group unit with internal court and solar appliance. 


\section{City and oasis development}

Gardens' City will be developed in four stages as shown in figure 9(a) and the whole oasis will be developed in parallel with Gardens' City (figure 9(b)).

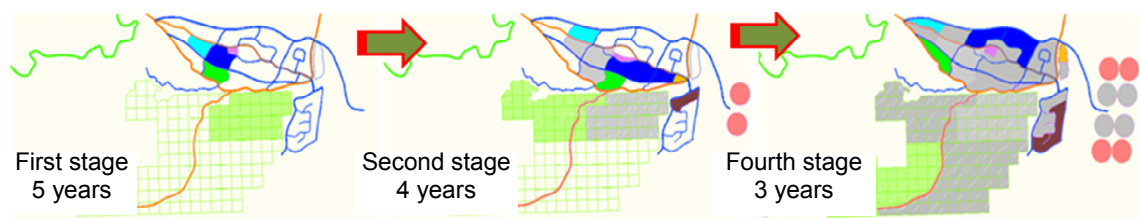

(a) Gardens' City development stages

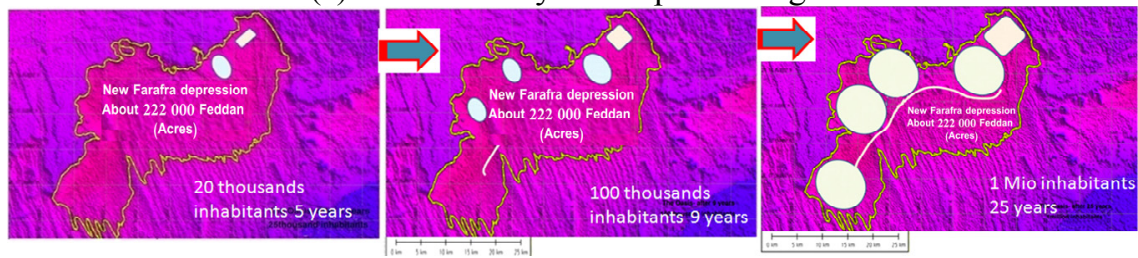

(b) New Farafra Oasis development

Figure 9: Gardens' City and the new Farafra Oasis development.

\section{$7 \quad$ Feasibility study}

\subsection{Gardens' City level}

Gardens' City palm gardens will produce 123,200 palm trees, which produce 12,320 palm tons yearly with a net profit of between 27-36 million Egyptian pounds $(1$ Egyptian pound $=0.145163 \mathrm{US} \$$ ). Olive gardens will produce 2508 olive tons with a yearly net profit of 6.6 million of Egyptian pounds. A produced 42,000 tons of wheat will have a net profit of between 30-48 million Egyptian pounds (see table 3 ).

\subsection{New Farafra Oasis level}

Palm production on the whole oasis level will be 100 million tons from one million palm trees with a net profit yearly between 222-291 million Egyptian pounds. About 20 million tons of olive will be produced from 633,600 olive trees with a net profit of 52 million Egyptian pounds. A net profit of 120-192 million Egyptian pounds will be gained from 1.680 million tons of wheat produced from 60,000 feddans (see table 4).

\section{Steps on the road}

The Gardens' City project was discussed by the Egyptian Shura Council on April 2012. On $29^{\text {th }}$ August 2012, a conference was held in the new valley governorate in Egypt to announce the start of the new Farafra Oasis development. 10 million Egyptian pounds have been assigned to drill experimental wells in the oasis. An 
Egyptian ministerial committee has been formed to investigate financing the new valley governorate. A conference was held in the new valley governorate on $27^{\text {th }}$ November 2012 to investigate financing the governorate in the presence of different ministers. A team of Assuit university professors from different colleges and specialities are developing the studies of the Gardens' City project forward. Now, investing opportunities are open in the new Farafra oasis for investors in different related agricultural and industrial fields.

Table 3: Feasibility study on Gardens' City level [3, 4, 11-15].

\begin{tabular}{|l|l|l|l|}
\hline Kind & Wheat & $\begin{array}{l}\text { Olive } \\
\text { Gardens }\end{array}$ & Palm Gardens \\
\hline Area (feddan) & 15,000 & 660 & 770 \\
\hline Avg. trees no./feddan & - & 120 & 160 \\
\hline Total trees no. in Gardens' City & - & 79,200 & 123,200 \\
\hline Avg. productivity & - & 31.6 & $100 \mathrm{~kg} /$ tree \\
\hline Productivity ton/feddan & 2.8 & 3.8 & 16 \\
\hline Total production (ton) & 42,000 & 2508 & 12,320 \\
\hline Production cost/feddan & $3250-4000$ & 1400 & \\
\hline Net profit/feddan LE & $2000-3200$ & 10,000 & $36,150-47,260$ \\
\hline Net profit/Gardens' City Mio & $30-48$ & 6.6000 & $27.8355-36.3902$ \\
\hline
\end{tabular}

Table 4: Feasibility study on new Farafra Oasis level.

\begin{tabular}{|l|l|l|l|}
\hline Kind & Wheat & Olive Gardens & Palm Gardens \\
\hline Area (feddan)-extended city & 15000 & 1320 & 1540 \\
\hline Trees no after extension & & 158399 & 246,300 \\
\hline Productivity ton-extended city & 42000 & 5015 & 24,630 \\
\hline Area feddan/oasis & 60000 & 5280 & 6160 \\
\hline Trees no/oasis & - & 633600 & 1 Mio \\
\hline $\begin{array}{l}\text { Total production (thousand } \\
\text { ton) }\end{array}$ & 1680 & 20.064 & 100,000 \\
\hline Production cost oasis/Mio LE & $195-240$ & 7.392 & \\
\hline Net profit Mio LE/oasis & $120-192$ & 52.800 & $\begin{array}{l}222.684- \\
291.122\end{array}$ \\
\hline
\end{tabular}

\section{Conclusion}

This paper discusses a general master plan of Gardens' City in new Farafra Oasis in newly discovered areas in Egyptian western desert. This city will be the first product of big development opportunities in Egypt. The city will be sustainable in energy, agriculture, land use, rest and residue etc. It will have four different kinds of renewable energy. It will have a yearly net profit of 63-90 million Egyptian pounds (LE), while the whole new Farafra Oasis will have 394-535 million LE of yearly net profits. Egypt needs to adopt such national projects. There are investment potentials in such projects in Egypt. 


\section{References}

[1] Ouda, K. et al., New Findings in Geology, Geomorphology, and Groundwater Potentiality of the Great Sand Sea, Western Desert, Egypt: An advantage which would lead to establishment of new societies in order to meet growing demands in Egypt. Geology of the Nile Basin Countries Conference (GNBCC - 2012): Geology and development challenges, March $20^{\text {th }}$ and March $22^{\text {nd }} 2012$, Alexandria (Egypt).

[2] Ouda K., (presented conf.): Fostering sustainable water management and agriculture in Egypt's 'New Valley' WaDImena Egypt - June 2009.

[3] Egyptian Solar Radiation Atlas.

[4] Wind Atlas for Egypt. www.windatlas.dk/egypt/About.html

[5] Edwards, Clive A., The importance of integration in sustainable agricultural systems. Agriculture, Ecosystems \& Environment. Volume 27, Issues 1-4, November 1989, Pages 25-35.

[6] Renewable energy - clean \& costless energy for our people living in suburbs and countryside, http://energy4poor.blogspot.com/p/blogpage.html

[7] Eloseiry E., Nuclear energy and the claim could be replaced by solar energy 4 Sept. 2012. http://today.almasryalyoum.com/article2.aspx? ArticleID $=352102$

[8] A utility-scale wind plant will require about 50 acres per megawatt http://www.tradewindenergy.com/windlibrary sub.aspx?id=136

TradeWind Energy at the heart of power, 2013 TradeWind Energy, Inc

[9] Desert power 2050 - DII Gmbh. executive summary - Studying Desert Energy, 2012.

[10] WWF The energy report - 100\% renewable energy by 2050, 2011. (WWF2011).

[11] Gamal El-Deen Z., Golden wheat spike - the national project to achieve self-sufficiency in wheat. Journal of citizens abroad. No. 20, 2011.

[12] Madian A., Application research results on crops (bananas-palms-olive, etc) in fruits Orchards development series - 2 July 2013, http://kenanaonline.com/users/alaamadian/posts/542247

[13] Mohamed M., E. Saad El-Deen, Olive planting and production. Horticulture Research Institute (HRI). Bulletin No. 720 of 2002. ARC. Central Administration of agricultural extension. Ministry of Agriculture and Land Reclamation. http://www.vercon.sci.eg/indexUI/uploaded/zyton \%20production/zyton \%20production.htm

[14] Ebrahim, K. Korish, Al-ahram-Farafra and East-Oweinat - Luminous stars in the heart of desert- 40 thousands Feddans have been planted with wheat, barley and export crops - 3 April 2008. http://www.ahram.org.eg /Archive/2008/4/3/Mhfz1.htm

[15] El-Gendy M., Comparison between the acreage and amount of wheat crop for the years 2012-2013. http://gate.ahram.org.eg/Page/96/Wheat.aspx 